RESEARCH ARTICLE

\title{
LEGAL PROTECTION FOR CHILDREN AS VICTIMS OF VIOLENCE
}

\author{
Evan Ferdiyan Rachmanto ${ }^{1 凶}$ \\ ${ }^{1}$ University of Tanjungpura, Pontianak, Indonesia \\ $\bowtie$ evanferdiyanr@gmail.com
}

\section{CITED AS}

Rachmanto, E. F. (2021). Legal Protection for Children as Victims of Violence.Journal of Law and Legal Reform,2(4), 515-526. https://doi.org/10.15294/jllr.v2i4.48758

\section{Submitted: December 7, $2020 \quad$ Revised: March 11, $2021 \quad$ Accepted: July 11, 2021}

\section{ABSTRACT}

A child contains human right, including those employing adult, children do not have much to think about and take concrete steps. In Indonesian, laws relating to Positive Law, is The Law No. 23 of 2002 on Child Protection have been amended by Law No. 35 of 2014 on Child Protection, which is very significant in reducing the level of violence against children. Legal protection for Children begins early in the womb birth. In its development there are children are in the environment is full of violence. Various social deviations that occur in the community more and most of the children. So that the perpetrators of violence do not feel deterred and no longer do the crime.

Keywords: Child Protection; Legal Protection; Victims of Violence 


\section{INTRODUCTION}

A child as one of the human resources and the future generation, it should get special attention from the government, in order to develop the child to achieve a strong human resources and quality. In connection with the child guidance necessary legal infrastructure to anticipate any problem that arise. Speaking of children, is very important thing for a child is a potential human fate on the day to come, and it was he who should participate in the history of the nation as well as mirror the attitude of the nation in the future (Magfur, 2003; Krisnawati, 2005; Mangku \& Yuliartini, 2021).

The Law No. 23 of 2002 on child protection or Article 1(1) of Law No. 35 of 2014 on the amenment of the Act No. 23 of 2002 on the protection of children is a child is a person under 18 (eighteen) years old, including children who are still in the womb. Article 28 B (2) UUD 1945 Constitution states that every child has the right to live, grow and develop and are entitle to protection from violence and discrimination (Seokanti, 1984; Krisnawati, 2005; Krisna, 2018).

Violence is often performed in conjunction with one of the forms of crime, violence can be done by force or threat of violence carried out or what tools were used, each depending on cases that arise. Actions can be happen to anyone, whether male or fermale, from children to adults, especially if the violence occurs within the scope of household, often violence is called the hidden crime (crime hidden) so called because the perpetrators an victims attempted to conceal such actions from public view, sometimes also referred to domestic violence.

Violence against children is a problem that is quite complex, because it has a serious negative impact, both for the victim and his social environment. In general violence is defined as an action taken another individual to individual resulting in physical or mental disorders (Sholihah, 2018; Arliman, 2017; Hasibuan, 2019).

Some previous studies confirmed that there are several reasons children become victims of violence that is still many people do not know exactly the rights of children. So that the child is considered under the aouthority of the parents and can be treated according to the will of the parents. Thought there are the rights of children to know their parents. One of them is the right to be protected. The next Cause is happening in society due to various factors including education and the economy. With a low parental education, they do not fully understand their rights (Wiyono, Arofa, Wulansari, \& Susanto, 2020; Aprilianda, 2017; Faridah \& Afiyani, 2019) .

The impact of violence against children are most felt that the traumatic experience that stubborn in children, which can lead to other problems of physical, psychological, and social. The definition of child is and individual who 
has not attained the age of 18 years. Therefore, violence against children is an act that is done a person / individual to those who have not reached the age of 18 who cause physical and or mental condition impaired.

\section{METHOD}

The research method aims to study one or more of the symptoms by analyzing road and by instituting a deep examination of the facts and then seeking a solution to the problem posed by the fact. The method can be used to analyze, learn, and understand, the circumstances at hand, so that the research method it self is a very omportant factor in study. This paper carried a nomantive, where due to the concerns od researchers looked at events that often happen to children where the children are an asset in the development of the nation. Researchers looked at how legal product that is made on whether legislation can reduce, minimize oe eliminate further violence incidentds to children. This study uses normative legal research (Soekanto, 2008; Abdulkadir, 2004; Maulana, 2000). This study uses secondary data from primary legal materials sourced from legislation that is used as well as articles that related with this write.

1. Approach and Personality Research Methods Normative approach, is identified as a norm of law rules or the Act (the act). While the nature of a descriptivestudy to look at law in the real sense, and examine how the working of the law in society.

2. Types and Sources of Data Research uses literature research. By means of legal materials, in an effort to produce arguments, theories and concepts as prescriptions in solving problems. Sources of data in research using primary legal materials, and materials secendary Law. This will examine the effevtiveness of a Law.

\section{LEGAL PROTECTION AGAINST CHILDREN}

Whithin the scope of Indonesian Dictionary, the definition of a child that can be concluded is that offspring are both, which means that from a ma and a woman giving birth, in which offspring are biologically derived from egg man then multiply in the woman uterus in the form of a woman's womb and than in due course give birth to offspring. According Supomo in Nandang Sambas (2003: 1) a child is from infancy to childhood past, namely from birth until the age of 12 years. Howecer, due to know theirs adolescence, then after childhood is over, a child can not be categoriezed as an adult, but rather just a teenager. In legislation, there are various descriptions about the definition of a child. According to Law 
No. 35 of 2014 on the Amendment of Act Number 23 of 2002 on child Protection states that the child is a person under 18 (eighteen) years old, including an unborn child. Later in Act No. 39 of 1999 about Human Rights in Pasal 1 ayat 5 states that a child means every human being below the age of 18 (eighteen) years old and unmarried, including children who are still in the womb when it is in his interest, and it is in line white the Regional Regulation of Semarang No. 5 of 2016 on chapter 1 pasal 14, that child is a person under 18 years old, including the unborn child.

Children are the next generation of a nation, then the child also has a right that must be recognized and protected by the state. The rights of children are also part of human rights even though the child still in the womb of a mother. The following are the rights of children according to same legislation in force in Indonesian, among others :

1. Law No. 4 of 1979 on Child Welfare

2. Law No. 39 of 1999 on Human Rights

3. Act No. 35 of 2014 on the Amendment of Act No. 23 of 2002 on Child Protection.

The background of the issuance of Law No. 23 of 2002 on the protection of children is due to the State of Indonesian which encures the well-being of each of its citizens, including the protection of children's rights that onstitute Human Rights as contained in the 1945 constitution and the UN convention on children's rights, Law 23 of 2002 was amended by Act 35 of 2014, the reasons do channge and renewal for Law No. 23 of 2002 has not been able to be a tool to prevent violence against children and protect children's rights. Explanation of Law 23 of 2002 on the protection of children said althought Law No. 39 on Human Rights has been inclued on children's rights, implementation of the obligations and responsibilities. It is reiterated thought Law No. 35 of 2014 using the 1945 and the Convention on the Rights of the Child (Convention on the Right of the Child), which was ratified by the Indonesian government through Presidential Decree No. 36 of 1990. Through Law No. 35 of 2014, aim to provide protection against Indonesian children from all forms of discrimination and violence is emphasized. UU No. 35 of 2014 has added a definition of violoence that previously did not exist in the Law No. 23 of 2002. The pupose of the law on child protection is to protect the child from alla forms of physical, emotional, social, and sexual, neglect, acts of harm, exploitation, and economic (Zahra \& Sularto, 2017; Nugraha, Izzaty, \& Putri, 2019).

Then, what is meant by the protection of children them selves are all efforts aimed to prevent, rehabilitate and empower children who experience acts abuse, 
exploitation and neglect in order to ensure the survival and development of the child fairly, both physical and social (Soeady \& Zulfikhair, 2014: 4). Child protection is an entire community efforts and activities in a variety of notch position and role are fully aware of the importance of children for the country in the future (Adebayo, 2020; Wangi, 2017; Octaviana, 2019). It is generally known that child protection is all the work done to create condition so that every child can exercise the rights and obligations for the development and growht of children is reasonably good physical, mental and social, including the education rights (Putri \& Iswari, 2021; Sulistiyono, Arifin, Sumardiana, \& Ramada, 2019).

The probelm child is not a small problem, but the children are the next generation of the nation and state (Syuhada, 2020; Aji, 2019). Factors that support sevices to child victims of crime, it was reaffirmed bye Arif Gosita are as follows :

1. The desire to expand fair treatment of children and improving the wlfare of children.

2. Welfare laws to support the implementation of services to child victims of cream.

3. Means that can be used to bring services to children as crime victims (Gosita, 2014)

Therefore, an obligation for the older generation to ensure, maintain, and secure the interests of the child. Maintenance, warranty, and safeguard the interests shoould be done by those who nurture the family (Anggriani, 2020; Wibowo, 2020; Putri, 2019). Viewed from theory of Legal Protection, child protection is a business that held the circumstances that enable the implementation of childern's as victims in accordance to Law No. 35 of 2014 contained in Article 64 (3), that children as victims get:

1. Rehabilitation of both the institution and outside the institution.

2. Safeguards and the preaching of identity through mass media to avoid labeling.

3. Provision of safety guarantess for witnesses and expert witnesses victims of physical, mental, and social.

4. Provision of accessibility to information about the develpment of the case (Julia, 2010: 196). 


\section{CHILDREN AS VICTIMS OF VIOLENCE}

Violence is a threat or use of physical force to inflict damage on others. In connection with the violence, social learning theory explains that childern learn new behaviors through observation of the models, imitate and practice into real behavior.

Violence in various forms the motif of some behaviors Indonesian culture that until now the mainstream that reduced values national identify and gives the impression of how climate solidarity humans has not been fully able to have a personality instropective political, economic and social personality of the nations and give an impression of how climate solidarity humans has not been fully able to have a personality instrospective, politically, economically and socially (Magfur, 2003). M Marwan and Jimmy (2009) stated that violence is nature or characterized by hard, resulting in injury or death of another person to physical damage, or goods or correcions. Violence had become familiar with the daily life of our society. Conflict resolution is always accompained by acts of violence. The acts of violence that often occurs not only done by individuals as members of society, but also by the state.

1. Shape Forms of Violence

Violence crime in the code of penal (penal code), the settings are not united in a special chapter, but separated in a particular chapter. Violent crime in the criminal code DAPT classified as follows (Susilo, 1991).

1) Crimes againts the life of another Article 338-350 of the Criminal Code

2) Crime malteatment Article 351-358 of the Criminal Code

3) Crimes such as burglary, hold-up, robbery of Article 365 of the Criminal Cide

4) Crimes againts decency, Particulary Article 285 of the Criminal Code

5) Crimes that cause death or injury negligence, Article 359-367

Under the Criminal Code classification forms of violence are divided into there categories as stated by Galtung (1992), namely :

a. Physical violence is the most easily recognizable, this kind of violence category is throwing, kicking, hitting/ slapping, choking, pushing, biting, banging, threatened whit sharp objects an so on. Victims of this kind of violence is usually looked directly on the physical casualties such as bruising, bleeding, fractures, fainting and other forms of the condition is more severe. Real violence that can be seen, felt by the body, untul the removal of a person's life. 
b. Psychic Violence of this kind is not so easy to recognize, as a result of the perceived victim did not leave scars cleary visible to others. The impact of this violence will affect thye situation of feeling unsafe and uncomfortable, the decline in self-esteen and dignity of victims, concrete manifestation of violence or violation of this type is the use of harsh words, abuse of turst, humiliate in front of others or in public, made threats with words and so on. Due to such behavior are usually the victims will feel inferior, insecure, fell worthless and weak in decision making. Violence which aims at spiritual or soul that can reduce or eveneliminate the ability of normal people. Example : lies, brainwashing, threarts and pressure.

c. Sexual violence in the form of maistreatment from others, activities that lead to pornography, sayings porn and postitution involving children in the process and so forth. Included in this category are all actions that appear in the form of coercion or threatening to have sexual intercourse, to torture or cruel actand leave, including those belinging to the age of the children. After conducting sexual relations any behavior that leads to acts of sexual abuse againts children Abik at school, in the family, and the environment around the child's residence included in the category of violence (Erdianti \& Al-Fatih, 2019; Latifiani, 2019; Setiawan, Saifunuha, Kautsar, \& Wulandari, 2019).

2. Violence Againts children

In terms of child abise known to abuse. Abuse is a word usually translated into violent persecution, torture or mistreatment. In this case Richard J. Gelles defines child abuse as "Internationa act that result in physical or emotional harm to Children. The term child abuse convers a wide range of behavior, from actual physical assault by parents or other adult caretakers to neglect at a child's basic needs" (Huraerah, 2006).

Meanwhile Barker defines violence againts children is the hurt of repeated physical and emotional abuse of child dependency, via urges, corporal punishment are uncontrollable, degradation and insults permanent or sexual violence, usually done by parents or others should care for the child. (Wahid, 2001).

Marzuki Umar Sa'abah argued (child abuse) is an act againts a child in a way that consciously or not resulting in disturbing the growth process of children. That can lead to physical disability, mental and even deadth in children (Saba'ah, 2006). Forms of Violence againts Children Types of violnece againts children (Yanti, et.al., 2006) as follows:

1) Physical violence is an act that causes pan or the potential to cause pain that is done by others, can occur once or repeatedly as being hit, kicked, slapped, piched, hit with a hard object, dried in the sun. 
2) Sexual violence is the involvement of children in sexual activities that are not understood as mistreatment from others, activities that lead to pornography, saying porn, sexual immorality and promiscuity in children who do others with no responsibility, levels encourage or forcing a child to engage in sexual activity which is unlawful as involved in prostituon.

3) Psychological violence is anything that can cause delays in psychological development of children as word that treaten, frighten, speak ridely, mocked, discriminated againts, limit sicial activities and creation.

4) Economic violence (commercial exploitation) is the used of children for work and other activities to wards the needs of the parents or others such as having the child work excessively, plunges children to prostitution for economic interest.

5) Acts pf neglect and abandoment is the indifference of the parents, the person responsible for the child on their needs as neglect on children's helath, abandoment and neglect on children's education, the neglect of the development of emotional, neglect on nutrition, abandonment and neglectin the procision of housing, abandoment conditions of safety on comfort.

While other forms of violence against children as stated by Mufidah (2006) seven most prevalent form of violence, which are as follow:

1) Violence in physical form such as beatings, severe abuse that causes sickness, even deadth.

2) Psychological violence such as threats, harassment, less pleasant attitude that causes fear, low self-esteem, trauma, depression or crazy.

3) Economic abuse, such as neglect of children.

4) Sexual violence in the form of sexuak harassement, sexual abuse and rape.

5) Labor exploitation and the worst froms of child.

6) Commercial sexual exploitation of children.

7) Trafficking (trade) child

Based on the notions of violence that has been described previously, it can be an outline that acts of violence that occur in children has been regulated in Law No. 35 of 2014 in Child Protection.

\section{HOW INDONESIA PROTECTS THE CHILDREN? A LEGAL COMMITMENT ON CHILD PROTECTION}

Efforts in violence for children with the formulation of legislation animed at eliminating discrimination against children, realized with the plan formulation 
and passage of legislation which is strongly associated with their interests, therefore the criminal policy against child abuse is one of efforts to implement their formulation. Criminal policies or efforts to combat crime is essentially an integral part of efforts to protect the public (social defense) and efforts to achieve public welfare (social welfare) Hence it can be said that the ultimate goal or primary purpose of the criminal policy is the protection of society to prosper community. Criminal policy is essentially an integral part of social policy.

\section{CONCLUSION}

This study concluded that the protection of children is a fundamental right that must be obtained by a child, each child entitled to then protection of the family, the community, and the government. In the operation of child protection contained in Law No. 23 of 2002 as amended by Act 35 of 2014 on the protection of children, all parties have an obligation to protect children and defend the rights of the child. Child protection all the efforts made to create conditions so that every child can exercise the rights and obligations for the development and growth of children is reasonably good physical, mental, and sicial. Child abuse is any act whether intentional or unintentional that can damage the child in the form of physical attacks, mental, social, economic, and sexual abuse of human rights, is contrary to the values and norms in society. Some of the factors triggering violence against children according to the National Child Protection Committee trigger of violence against children that occur include : the family structure, the inheritance of violence from generation to generation, social stress and social isolation, as well as community involvement under. These forms of violence against children, namely: physical abuse, emotional abuse, verbal abuse, sexual violence, adn social violence. Basically everyone is prohibited violence in the home for children in the home scope ladder, including one of them physical abuse and if the perpetrator is biological parents then his punishment will be more svere.

\section{REFERENCES}

Abdulkadir, M. (2004). Hukum dan Penelitian Hukum. Bandung: Citra Aditya Bakti. Adebayo, A. A. (2020). Religions and Legal Regimes Function in the Protection of Children. JILS (Journal of Indonesian Legal Studies), 5(2), 335-360.

Aji, W. S. (2019). The Implementation of Diversion and Restorative Justice in the 
Juvenile Criminal Justice System in Indonesia. JILS Journal of Indonesian Legal Studies), 4(1), 73-88.

Anggriani, E. P. (2020). Policy on Reducing Child Labor as the Elimination of the Worst Forms of Child Labor. Unnes Law Journal: Jurnal Hukum Universitas Negeri Semarang, 6(1), 1-20.

Aprilianda, N. (2017). Perlindungan anak korban kekerasan seksual melalui pendekatan keadilan restoratif. Arena hukum, 10(2), 309-332.

Arliman, L. (2017). Peranan Pers Untuk Mewujudkan Perlindungan Anak Berkelanjutan di Indonesia. Jurnal Ilmu Hukum Tambun Bungai, 2(2), 126145.

Candra, M. (2018). Aspek Perlindungan Anak Indonesia. Jakarta: Prenada Media.

Erdianti, N., \& Al-Fatih, S. (2019). Fostering as an Alternative Sanction for Juveniles in the Perspective of Child Protection in Indonesia. JILS (Journal of Indonesian Legal Studies), 4(1), 121-128.

Faridah, S., \& Afiyani, L. (2019). Isu Pekerja Anak dan Hubungan Dengan Hak Asasi Manusia. Lex Scientia Law Review, 3(2), 163-176.

Galtung, J. (1992). Kekuasaan dan Kekerasan. Yogyakarta: Kanisius.

Hasibuan, L. R. (2019). Hak Restitusi Terhadap Korban Anak Berdasarkan Undang Undang Nomor 35 Tahun 2014 Tentang Perubahan Atas UndangUndangnnomor 23 Tahun 2002 Tentang Perlindungan Anak di Belawan. Jurnal Hukum Responsif, 7(2), 30-39.

Huraerah, A. (2006). Kekerasan Terhadap Anak. Bandung: Nuansa.

Krisna, L. A. (2018). Hukum Perlindungan Anak: Panduan Memahami Anak yang Berkonflik dengan Hukum. Jakarta: Deepublish.

Krisnawati, E. (2005). Aspek Hukum Perlindungan Anak. Bandung: CV Utomo. Latifiani, D. (2019). The Darkest Phase for Family: Child Marriage Prevention and Its Complexity in Indonesia. JILS (Journal of Indonesian Legal Studies), 4(2), 241-258.

Magfur, M. (2003). Anatomi Kekerasan Manusia antara Entitas Mencinta dan Kematian Dalam Pemikiran Pekikiran Revolusioner. Malang: Qaverroes Press. Mangku, D. G. S., \& Yuliartini, N. P. R. (2021). Legal Protection of Children in Armed Conflict in the View of International Humanitarian Law. IJCLS (Indonesian Journal of Criminal Law Studies), 6(1), 1-10.

Marwan, M., \& Jimmy, P. (2009). Kamus Hukum. Surabaya: Reality Publisher.

Maulana, H. W. (2000). Pengantar Advokasi Perlindungan Anak. Jakarta: PT Gramedia.

Mufidah, M. (2006). Haruskah Perempuan dan Anak Dikorbankan. Papringan: Pilar Media. 
Nugraha, X., Izzaty, R., \& Putri, A. A. (2019). Rekonstruksi Batas Usia Minimal Perkawinan Sebagai Bentuk Perlindungan Hukum Terhadap Perempuan (Analisa Putusan MK No. 22/Puu-Xv/2017). Lex Scientia Law Review, 3(1), 40-54.

Octaviana, S. N. (2019). Child Sexual Abuse in Indonesia: History and Challenge in Legal Perspective. IJCLS (Indonesian Journal of Criminal Law Studies), 4(1), 83-92.

Paulus, H. (2008). Delikuensi Anak Pemahaman dan Penanggulangnnya. Malang: Banyumedia Publishing.

Putri, I. M. R., \& Iswari, R. (2021). Sekolah Ramah Anak: Kerja Sama Sekolah dan Orang Tua Siswa di SMP Negeri 26 Semarang. Solidarity: Journal of Education, Society and Culture, 10(1), 49-58.

Putri, Y. R. (2019). Children Abandoning Parents: What about Legal Sanctions?.Unnes Law Journal: Jurnal Hukum Universitas Negeri Semarang, 5(1).

Republic of Indonesia. (1945). Undang-Undang Dasar Negara Republik Indonesian Tahun 1945.

Republic of Indonesia. (2014). Law No. 35 of 2014 on the amenment of the Act No. 23 of 2002 on the Protection of Children.

Sa'abah, M. U. (2006). Perilaku Seks Menyimpang dan Seksualitas Konterporer Umat Islam. Yogyakarta: UII Press.

Sekanto, S. (2008). Pengantar Penelitian Hukum. Jakarta: UI Press.

Setiawan, S., Saifunuha, M. A., Kautsar, J. L., \& Wulandari, C. (2019). Community empowerment on establishment of friendly-village for women and children. Indonesian Journal of Advocacy and Legal Services, 1(1), 5-22.

Sholihah, H. (2018). Perlindungan Anak dalam Perspektif Hukum Islam. Al-Afkar, Journal for Islamic Studies, 1(1, January), 38-56.

Soekanti, S. W. (1984). Anak dan Wanita dalam Hukum. Jakarta: LP3ES.

Soesilo, R. (1991). Kitab Undang-Undang Hukum Pidana Serta Komentar Pasal Demi Pasal. Bogor: Politea.

Sudarto, S. (1981). Hukum dan Hukum Pidana. Bandung: PT. Alumni.

Sulistiyono, T., Arifin, R., Sumardiana, B., \& Ramada, D. P. (2019). Legal Protection to Child Labour: The Effectiveness of National Criminal Law and International Law Instrument (A Case Study of Indonesia and China). International Journal of Business, Economics and Law, 18(4), 45-52.

Syuhada, E. A. (2020). Legal Protection of Street Children for Exploitation in Criminal Law Perspectives. IJCLS (Indonesian Journal of Criminal Law Studies), 5(1), 15-20. 
Wahid, A. (2001). Perlindungan Terhadap Korban Kekerasan Adokasi atas Hak Asasi Perempuan. Bandung: Refika Aditama.

Wangi, Y. D. T. (2017). Policy of Development for Juvenile Delinquency in the Perspective of Indonesian Criminal Justice System Reform (Study on Institute for Special Development Children LPKA Kutoarjo, Central Java, Indonesia). JILS (Journal of Indonesian Legal Studies), 2(2), 85-100.

Wibowo, S. A. (2020). Child Sexual Violence and the Violation of Human Rights: The Darkest Side of Law Enforcement in Indonesia. The Indonesian Journal of International Clinical Legal Education, 2(4), 421-434.

Wiyono, B., Arofa, E., Wulansari, E. M., \& Susanto, S. (2020). Sosialisasi UndangUndang KDRT dan Perlindungan Anak.Jurnal Abdimas Tri Dharma Manajemen, 1(3), 42-47.

Yanit, M. D. A., et.al. (2006). Model Sistem Monitoring dan Pelaporan Anak dan Perempuan Korban Kekerasan. Propinsi Jateng: Bapenas.

Zahra, A., \& Sularto, R. B. (2017). Penerapan Asas Ultimum Remedium dalam Rangka Perlindungan Anak Pecandu Narkotika. Law Reform, 13(1), 18-27. 